\title{
Expectation Gap pada Persepsi Auditor Internal dengan Auditee terkait Kompetensi, Independensi, dan Kualitas Audit
}

\author{
Linda Dewi Puspita Sari ${ }^{1}$, Tri Widyastuti ${ }^{2}$ \\ ${ }^{1}$ Universitas ... \\ ${ }^{2}$ Universitas Bhayangkara Jakarta
}

INFO ARTIKEL

JEL Classsification:

M42

Keywords:

expectation

gap, perception,

competency,

independency, quality

of audit.

\begin{abstract}
Mapping result of State Development Audit Agency for Inspectorate General of Ministry of Agriculture by Internal Audit Capability Model was on second level (Infrastructure) and the audit result of State Audit Agency was unqualified opinion, but there was notes for assets arrangement and Inspectorate General was rated that it gave a contribution. On the other hand, the result of internal assesment was on good category. This research aims to analyze expectation gap between internal auditor's perception and perception of auditee for competency, independency, and quality of audit. Population in this research consist of internal auditor and auditee represented by audited work units under the annual audit work program in 2017. Sampling using the Slovin formula and on data collection obtained data as much as 58 auditors and 82 auditee. Method of data analysis using independent t-test. The result show there is an expectation gap between internal auditor's perception and perception of auditee for independency and internal auditor's quality of audit but there isn't an expectation gap between internal auditor's perception and perception of auditee for competency.
\end{abstract}

\begin{abstract}
ABSTRAK
Hasil pemetaan Badan Pengawasan Keuangan dan Pembangunan terhadap Inspektorat Jenderal Kementerian Pertanian dengan pendekatan internal audit capability model masih pada level 2 (infrastructure) dan hasil pemeriksaan Badan Pemeriksa Keuangan atas Laporan Keuangan Kementerian Pertanian Tahun 2016 adalah Wajar Tanpa Pengecualian, namun masih terdapat beberapa catatan antara lain penataan aset yang dinilai belum memadai dan Inspektorat Jenderal dinilai publik turut serta memberikan andil. Di sisi lain, hasil penilaian internal menunjukkan nilai yang relatif baik. Penelitian ini menganalisis apakah terdapat expectation gap antara persepsi auditor internal dan auditee terkait dengan kompetensi, independensi, dan kualitas audit. Populasi dalam penelitian terdiri atas auditor Inspektorat Jenderal Kementerian Pertanian dan auditee yang diwakili jumlah unit/satuan kerja yang diaudit sesuai Program Kerja Audit Tahunan Tahun 2017. Pengambilan sampel menggunakan rumus Slovin dan pada pengumpulan data didapatkan data sebanyak 58 orang auditor internal dan 82 orang auditee. Metode analisis data menggunakan independent t-test menunjukkan terdapat expectation gap antara persepsi auditor internal dan auditee terkait dengan independensi dan kualitas audit dari auditor internal, namun tidak terdapat expectation gap antara persepsi auditor internal dan auditee terkait kompetensi auditor internal.
\end{abstract}

*Email Korespondensi: ${ }^{1}$ linda.ps86@gmail.com, ${ }^{2}$ triewidhiastuti@yahoo.com 


\section{Pendahuluan}

Pelaksanaan pengawasan internal lingkup Kementerian Pertanian merupakan tugas yang diemban oleh Inspektorat Jenderal Kementerian Pertanian sesuai Peraturan Menteri Pertanian Nomor 43/Permentan/OT.010/8/2015 tentang Organisasi \& Tata Kerja Kementerian Pertanian yang menetapkan tugas dan fungsi Inspektorat Jenderal yaitu melaksanakan penyiapan perumusan kebijakan teknis, pelaksanaan pengawasan intern terhadap kinerja dan keuangan melalui audit, reviu, evaluasi, pengawalan, pemantauan dan kegiatan pengawasan lainnya pada unit organisasi di lingkungan Kementerian Pertanian.

Dalam rangka peningkatan kualitas kinerja Auditor Internal sebagai Catalyst/Quality Assurance, Inspektorat Jenderal telah melakukan berbagai upaya di antaranya dengan melakukan penilaian internal meliputi faktor integritas, obyektivitas, independensi, profesionalisme, dan tanggung jawab pada pelaksanaan audit. Hasil penilaian pada periode tahun 2014-2016 menunjukkan nilai yang relatif baik dan terjadi kenaikan nilai (Skala penilaian $1-4$ dengan kategori kurang baik-sangat baik) baik dari tingkat Pengendali Mutu sampai tingkat Anggota Tim.

Hasil penilaian internal tersebut, dinilai belum dapat memberikan keyakinan kepada publik tentang kualitas kinerja terhadap Auditor Internal didukung hasil pemetaan oleh BPKP dengan menggunakan pendekatan Internal Audit Capability Model (IACM) menunjukkan bahwa hasil penilaian terhadap Inspektorat Jenderal Kementerian Pertanian pada Semester I Tahun 2017 masih berada pada level 2 (Infrastructure) dengan beberapa catatan di antaranya masih perlunya penyempurnaan SOP Audit, penyempurnaan Audit Universe, dan pembentukkan satgas IACM. Menyusul hasil pemeriksaan BPK atas Laporan Keuangan Kementerian Pertanian Tahun 2016, menunjukkan level opini
Wajar Tanpa Pengecualian (WTP) namun masih terdapat beberapa catatan diantaranya penataan aset yang dinilai belum memadai senilai Rp276.236.371.494,00 dan Inspektorat Jenderal dinilai publik memberikan andil atas permasalahan tersebut sebagai kelemahan pengawasan internal.

Hasil penilaian BPKP dan BPK yang tidak sejalan dengan hasil penilaian internal Inspektorat Jenderal Kementerian Pertanian tersebut, menjadi salah satu indikasi adanya kesenjangan harapan terhadap kinerja audit. Kesenjangan tersebut mampu menimbulkan adanya berbagai pertanyaan, tuntutan, komplain, dan kritik terhadap kinerja Auditor Internal sebagai bentuk ketidakpuasan masyarakat. Menurut Ebimobowei (2010), kesenjangan harapan audit adalah masalah yang sangat mendasar dalam setiap masyarakat di dunia. Kemungkinan bahwa auditor tidak mampu memenuhi harapan masyarakat menimbulkan expectations gap terkait persepsi tanggungjawab auditor (Siddiqui et al., 2008).

Audit expectation gap merupakan persoalan yang krusial terkait dengan fungsi audit independen dan memiliki implikasi yang signifikan pada perkembangan standar dan praktek audit (Lin dan Chen, 2004). Audit expectation gap dapat didefinisikan sebagai perbedaan antara apa yang masyarakat harapkan dari auditor dalam menjalankan tugasnya. Semakin tinggi harapan masyarakat yang tidak terpenuhi dapat menurunkan nilai yang diberikan masyarakat kepada auditor dan dapat mempengaruhi kredibilitas auditor sebagai seorang profesional.

\section{Telaah Teori dan Pengembangan Hipotesis}

\section{Persepsi Auditor Internal dan Auditee terhadap Kompetensi}

Kompetensi auditor adalah keterampilan, keahlian, dan kemampuan profesional yang 
diperlukan auditor untuk melaksanakan audit secara objektif. Kompetensi ditunjukkan pula dengan keharusan bagi setiap auditor untuk memiliki keterampilan atau kemahiran profesi auditor yang diakui umum untuk melakukan audit.

Berdasarkan teori persepsi, latar belakang pendidikan, keahlian yang diperoleh melalui berbagai upaya peningkatan kualitas, serta pengalaman yang cukup tinggi dapat mempengaruhi persepsi auditor internal sehingga mempersepsikan dirinya sebagai auditor yang kompeten. Robbins dan Timothy (1996) secara implisit menyatakan bahwa persepsi satu individu terhadap satu obyek sangat mungkin memiliki perbedaan dengan persepsi individu yang lain terhadap obyek yang sama, sehingga auditee memiliki kemungkinan untuk berbeda persepsi terhadap kompetensi auditor internal berdasarkan pengalaman audit sebelumnya, sikap, atau tujuan dari auditee tersebut.

Perbedaan persepsi ini menunjukkan adanya expectation gap (kesenjangan harapan) dimana harapan auditee terkadang lebih besar melebihi kompetensi auditor internal karena menganggap auditor sebagai consulting partner sesuai paradigma pengawasan saat ini. Semakin besar tuntutan terhadap kompetensi auditor internal menunjukkan besarnya expectation gap.

Halim dan Rusliyawati (2008) mendapatkan bukti empiris mengenai audit expectation gap antara auditor pemerintah (BPK) dan pengguna laporan keuangan pemerintah dilihat dari sisi kompetensi auditor, materialitas, bukti audit, pendapat wajar dan audit kinerja. Selain itu, Yudaruddin dan Rahman (2014) juga membuktikan bahwa terdapat expectation gap antara auditor internal dan auditee terkait dengan independensi, kompetensi profesional, dan pengawasan pada Inspektorat Kota Balikpapan. Berdasarkan penelaahan terhadap teori-teori yang terkait, hasil penelitian terdahulu, dan kerangka pemikiran teoritis terhadap variabelvariabel yang terjadi expectation gap, maka dikembangkan hipotesis sebagai berikut:
H1: Terdapat expectation gap antara persepsi auditor internal dan auditee terkait dengan kompetensi auditor internal.

\section{Persepsi Auditor Internal dan Auditee terhadap Independensi}

Independensi auditor yang didefinisikan sebagai kebebasan dari kondisi yang mengancam kemampuan aktivitas audit intern untuk melaksanakan tanggung jawab audit intern secara objektif, menuntut auditor internal untuk selalu menjaga independensi. Secara ideal, auditor internal memungkinkan untuk melaksanakan tugasnya tanpa berpihak. Auditor internal dapat mempertahankan sikap independensi dengan usaha (efforts) yaitu bersumber dari dalam diri auditor, bersifat tidak menetap, dan auditor dapat mengendalikannya.

Di sisi lain, auditor internal banyak menghadapi permasalahan dan kondisi yang menghadapkan auditor internal untuk mempertaruhkan independensinya. Pertimbangan sejauh mana hasil audit dapat mempengaruhi kelangsungan kerjanya, banyaknya kepentingan baik dari sisi auditor internalnya sendiri, organisasi auditor internal maupun organisasi auditee dapat mempengaruhi independensi auditor internal.

Kinerja auditor internal pada sektor publik (APIP) akhir-akhir ini menjadi pertanyaan, tuntutan, komplain, dan kritik dari masyarakat, terutama masalah independensi setelah muncul beberapa kasus suap yang melibatkan auditor antara lain kasus suap auditor Badan Pemeriksa Keuangan (BPK) pada pemberian opini Wajar Tanpa Pengecualian (WTP) pada Kementerian Desa, Pembangunan Daerah Tertinggal, dan Transmigrasi serta kasus suap terkait temuan pemeriksaan dengan tujuan tertentu terhadap kantor cabang PT Jasa Marga (persero) Purbaluenyi. Kasus suap tersebut merupakan bukti adanya ketidakindependensian dalam kinerja auditor.

Menurut Porter (1993), lingkungan audit yang penuh dengan kritikan terhadap kinerja auditor merupakan karakteristik dari lingkungan 
auditsaatini dan penyebab meningkatnya kritikan terhadap profesi audit karena kesenjangan harapan terhadap kinerja audit. Independensi adalah dasar keandalan dari laporan auditor. Laporan auditor akan tidak terpercaya jika auditor tidak independen. Semakin besarnya tuntutan akan independensi auditor internal akan menunjukkan besarnya expectation gap.

Yeni (2000) telah membuktikan adanya adanya perbedaan persepsi yang cukup signifikan antara pemakai laporan keuangan, auditor, dan mahasiswa akuntansi mengenai peran dan tanggung jawab auditor dalam isu tanggung jawab auditor terhadap fraud, independensi, tanggung jawab illegal act klien, dan perbaikan keefektivan audit. Rusliyawati dan Halim (2008) juga telah membuktikan secara empiris adanya audit expectation gap antara auditor pemerintah (BPK) dan pengguna laporan keuangan pemerintah dilihat dari sisi pelaporan, akuntabilitas, independensi auditor, kompetensi auditor, materialitas, bukti audit, pendapat wajar dan audit kinerja.

Berdasarkan penelaahan terhadap teoriteori yang terkait, hasil penelitian terdahulu, dan kerangka pemikiran teoritis terhadap variabelvariabel yang terjadi expectation gap, maka dikembangkan hipotesis sebagai berikut:

H2: Terdapat expectation gap antara persepsi auditor internal dan auditee terkait dengan independensi auditor internal.

\section{Persepsi Auditor Internal dan Auditee terhadap Kualitas Audit}

Kualitas audit didefinisikan sebagai ukuran mutu dari proses pemeriksaan yang sistimatis dengan pertimbangan profesional yang baik dan dilaksanakan oleh auditor yang kompeten serta independen sehingga menghasilkan level of assurance yang bermutu tinggi kepada masyarakat pemakai jasa audit.

Dalam konteks level of assurance dan peningkatan kinerja perusahaan, harapan auditee mungkin lebih tinggi karena auditee sebagai obyek audit. Seringkali pihak auditee memiliki sebuah problem yang sedemikian rumitnya sehingga perlu meminta bantuan dari auditor internal untuk bersama-sama mencarikan jalan keluarnya.

Tingginya harapan maupun tuntutan masyarakat atau auditee terhadap kualitas audit akan memunculkan expectation gap. Fakta empiris hasil penelitian oleh Adhikara (2012) membuktikan terdapat expectation gap antara auditor, investor, dan akuntan manajemen pada faktor responsibility, reliability, dan decision usefulness dari laporan hasil audit.

Hal berbeda ditunjukkan oleh Hutabarat dan Afri (2013), yang membuktikan adanya kesenjangan harapan audit dari sisi materialitas, namun tidak terdapat kesenjangan harapan audit dari sisi akuntabilitas, independensi, bukti audit, dan audit kinerja. Sedangkan dari sisi kompetensi dan kualitas pelaporan audit justru lebih persepsi pemakai laporan audit lebih baik dari persepsi auditor sendiri.

Berbicara masalah kualitas audit, merupakan hal yang harus terangkai mulai dari pelaksanaan, hasil, sampai pada tindak lanjutnya. Penelitian yang dilakukan oleh Simatauw (2014) menguji secara empiris expectation gap antara persepsi auditor internal dan auditee terhadap kinerja auditor internal terkait dengan pelaksanaan audit, hasil audit, dan tindak lanjut audit. Berdasarkan hasil pengujian data dan analisis data, dapat dinyatakan bahwa terdapat expectation gap antara persepsi auditor internal dan auditee terhadap kinerja auditor internal terkait dengan pelaksanaan audit dan tindak lanjut audit. Namun, tidak terdapat expectation gap antara persepsi auditor internal dan auditee terhadap kinerja auditor internal terkait dengan hasil audit. Berdasarkan penelaahan terhadap teoriteori yang terkait, hasil penelitian terdahulu, dan kerangka pemikiran teoritis terhadap variabelvariabel yang terjadi expectation gap, maka dikembangkan hipotesis sebagai berikut:

H3 : Terdapat expectation gap antara persepsi auditor internal dan auditee terkait dengan kualitas audit. 


\section{Metode Penelitian}

Populasi adalah wilayah generalisasi yang terdiri atas: obyek/subyek yang mempunyai kualitas dan karakteristik tertentu yang ditetapkan olehpeneliti untuk dipelajari dan kemudian ditarik kesimpulannya (Sugiyono, 2011). Penelitian ini dilakukan pada Kementerian Pertanian. Populasi dalam penelitian ini dikelompokkan menjadi dua yaitu, Auditor Internal yang merupakan auditor yang ada pada Inspektorat Jenderal Kementerian Pertanian meliputi auditor pada Inspektorat I, Inspektorat II, Inspektorat III, dan Inspektorat IV dan populasi kedua adalah auditee yaitu orang/ instansi pemerintah yang diaudit oleh APIP yang diwakili oleh pihak yang melaksanakan dan bertanggung jawab atas hal yang dinilai oleh auditor umumnya pejabat pengelola keuangan yang terdiri atas Kuasa Pengguna Anggaran, Pejabat Pembuat Komitmen (PPK), Bendahara dan penanggung jawab kegiatan.

Sampel adalah sebagian/wakil populasi yang akan diteliti (Arikunto, 1998). Berdasarkan hasil perhitungan dengan rumus Slovin didapatkan jumlah sampel untuk auditor internal adalah sebanyak 58 orang dan untuk auditee sebanyak 81 orang. Penentuan jumlah sampel kelompok auditor internal per masing- masing unit kerja (Inspektorat I, Inspektorat II, Inspektorat III, dan Inspektorat IV) dilakukan secara proporsional sesuai jumlah populasi per masing-masing unit kerja. Sedangkan untuk sampel kelompok auditee dilakukan dengan professional judgement

Pengumpulan data dilakukan untuk memperoleh informasi yang dibutuhkan dalam rangka mencapai tujuan penelitian. Pengumpulan data dalam penelitian ini dilakukan dengan dua metode yaitu metode studi lapangan dan studi kepustakaan.

Data yang diperlukan dalam penelitian ini terdiri dari data primer dan data sekunder. Data primer diperoleh melalui kuisioner yang telah diisi oleh auditor internal dan auditee, sedangkan data sekunder diperoleh melalui media perantara atau secara tidak langsung dan dalam penelitian ini diperoleh dari lokasi obyek penelitian (Inspektorat Jenderal Kementerian Pertanian) berupa data jumlah auditor, jumlah unit/satuan kerja, hasil penilaian individu lingkup Inspektorat Jenderal, dan data lainnya.

Ringkasan operasionalisasi variabel berdasarkan beberapa pustaka dan penelitianpenelitian sebelumnya disajikan pada tabel berikut:

Tabel 1. Tabel Operasionalisasi Variabel Penelitian

\begin{tabular}{|c|c|c|c|c|}
\hline $\begin{array}{l}\text { Variabel dan } \\
\text { Rujukan }\end{array}$ & Dimensi & Indikator & Skala & Kuis No \\
\hline \multirow{5}{*}{$\begin{array}{l}\text { KOMPETENSI } \\
\text { Yudaruddin dan } \\
\text { Taufikur Rahman } \\
\text { (2014); Rusliyawati } \\
\text { dan Abdul Halim } \\
\text { (2008); PER/05/M. } \\
\text { PAN/03/2008 }\end{array}$} & Pengetahuan & $\begin{array}{l}\text { - Pendidikan formal yang sudah } \\
\text { ditempuh }\end{array}$ & Interval & 1 \\
\hline & & $\begin{array}{l}\text { - Wawasan tentang } \\
\text { Pemerintahan }\end{array}$ & Interval & 2 \\
\hline & & $\begin{array}{l}\text { - Pengetahuan tentang bidang } \\
\text { tugas dan fungsi auditee } \\
\text { (Bussiness process) }\end{array}$ & Interval & 3 dan 4 \\
\hline & & $\begin{array}{l}\text { - Pelatihan, kursus dan keahlian } \\
\text { khusus yang dimiliki }\end{array}$ & Interval & 5 dan 6 \\
\hline & Pengalaman & - Lama melakukan audit & Interval & 7 s.d 10 \\
\hline
\end{tabular}




\begin{tabular}{|c|c|c|c|c|}
\hline $\begin{array}{l}\text { Variabel dan } \\
\text { Rujukan }\end{array}$ & Dimensi & Indikator & Skala & Kuis No \\
\hline \multirow{4}{*}{$\begin{array}{l}\text { INDEPENDENSI } \\
\text { Yudaruddin } \\
\text { Taufikur } \quad \text { Rahman } \\
\text { (2014); } \\
\text { (2005); Rastanti } \\
\text { dan Abliyawati } \\
(2008) ; \quad \text { PER/05/M. } \\
\text { PAN/03/2008 }\end{array}$} & Sikap Mental & - Sikap mental auditor internal & Interval & 11 dan 12 \\
\hline & Penampilan & $\begin{array}{l}\text { - Penyikapan auditor terhadap } \\
\text { faktor ketidakindenendensian }\end{array}$ & Interval & 13 s.d 15 \\
\hline & $\begin{array}{l}\text { Hubungan } \\
\text { dengan } \\
\text { Auditee }\end{array}$ & $\begin{array}{l}\text { - Adanya hubungan dengan } \\
\text { auditee }\end{array}$ & Interval & 16 s.d 18 \\
\hline & $\begin{array}{l}\text { Gangguan } \\
\text { dari Auditee }\end{array}$ & $\begin{array}{l}\text { - Adanya Fasilitas } \\
\text { - Permintaan auditee }\end{array}$ & $\begin{array}{l}\text { Interval } \\
\text { Interval }\end{array}$ & $\begin{array}{l}19 \text { s.d } 21 \\
22\end{array}$ \\
\hline \multirow{11}{*}{$\begin{array}{l}\text { KUALITAS AUDIT } \\
\text { Harhinto } \\
\text { Sutton } \\
\text { C h r i s t i a w a n } \\
(2002) ; \quad \text { Purnomo } \\
(2007) ; \quad \text { PER/05/M. } \\
\text { PAN/03/2008 }\end{array}$} & Kualitas & - Persiapan Audit & Interval & 23 s.d 25 \\
\hline & $\begin{array}{l}\text { Persiapan } \\
\text { Audit }\end{array}$ & & & \\
\hline & $\begin{array}{l}\text { Kualitas } \\
\text { Proses Audit }\end{array}$ & - Proses Audit & Interval & 26 dan 27 \\
\hline & Temuan Audit & - Keakuratan Temuan Audit & Interval & 28 dan 29 \\
\hline & & - Sikap Tidak Mudah Percaya & Interval & 30 \\
\hline & Rekomendasi & $\begin{array}{l}\text { - Kehati-hatian dalam } \\
\text { mengambil keputusan }\end{array}$ & Interval & 31 \\
\hline & & - Nilai Rekomendasi & Interval & 32 \\
\hline & Laporan & - Ketepatan Waktu & Interval & 33 \\
\hline & Audit & - Kejelasan Laporan & Interval & 34 s.d 36 \\
\hline & & - Manfaat Audit & Interval & 37 \\
\hline & & - Tindak Lanjut Hasil Audit & Interval & 38 dan 39 \\
\hline
\end{tabular}

Teknik analisis data dilakukan dengan uji beda menggunakan Independent-samples t-test $(\mathrm{Uji}-\mathrm{t})$. Pengujian Independent-samples t-test $(\mathrm{Uji}-\mathrm{t})$ dilakukan setelah uji validitas dan reliabilitas serta uji asumsi normalitas. Uji validitas dilakukan dengan dengan uji korelasi Pearson Moment antara masing-masing skor indikator dengan total skor konstruk. Uji reliabilitas diuji menggunakan rumus koefisien Cronbach's Alpha. Uji normalitas dilakukan menggunakan Uji Kolmogorof-Smirnov (Uji K-S).

Analisis deskriptif digunakan untuk mendeskripsikan atau menggambarkan obyek penelitian yang diambil dari sampel maupun populasi dan untuk menyajikan gambaran data tanggapan responden tanggapan responden terhadap setiap dimensi dan variabel yang sedang diteliti.

Uji validitas adalah untuk mengetahui sah tidaknya instrumen kuisioner yang digunakan dalam pengumpulan data. Uji Reliabilitas dimaksudkan untuk menguji konsistensi kuesioner dalam mengukur suatu konstruk yang sama atau stabilitas kuesioner jika digunakan dari waktu ke waktu. Uji normalitas, dilakukan untuk mengetahui kepastian sebaran data yang diperoleh terhadap data bersangkutan. 
Pengujian hipotesis 1 sampai 3 dilakukan dengan melihat hasil perhitungan uji-t independen. Jika $\mathrm{t}_{1-\alpha / 2}<\mathrm{t}<\mathrm{t}_{1-\alpha / 2}$ atau $P$-Value $<\alpha$ yang ditetapkan dengan $\mathrm{t}_{1-\alpha / 2}$ diperoleh dari daftar distribusi t dengan peluang $(1-\alpha / 2)$ dan $d k=\mathrm{n} 1$ $+\mathrm{n} 2-2$ maka hipotesis penelitian terbukti $\left(\mathrm{H}_{0}\right.$ ditolak dan $\mathrm{H}_{1}$ diterima).

\section{Analisis Hasil dan Pembahasan}

Penelitian ini bertujuan untuk mendapatkan bukti empiris expectation gap antara persepsi auditor internal dan auditee terkait dengan kompetensi, independensi, dan kualitas dari audit auditor internal. Sampel dianalisis dari kelompok auditor internal total sejumlah 58 orang yang tersebar di 4 (empat) unit kerja yaitu Inspektorat I dan IV masing-masing sebanyak 14 orang, Inspektorat II dan III masing-masing sebanyak 15 orang. Sedangkan sampel dari kelompok auditee dari kelompok auditee total sejumlah 82 orang yang tersebar di 11 (sebelas) unit/satuan kerja yang menjadi mitra auditor internal.
Hasil uji validitas menunjukkan bahwa 10 item pernyataan kuesioner Kompetensi Auditor $\left(\mathrm{X}_{1}\right), 12$ item pernyataan kuesioner Independensi Auditor $\left(\mathrm{X}_{2}\right)$, dan 17 item pernyataan kuesioner Kualitas Audit $\left(\mathrm{X}_{3}\right)$ baik pada kuisioner untuk kelompok sampel auditor internal maupun auditee seluruhnya dinyatakan valid karena nilai Pearson Correlation > rtabel. Hasil uji reliabilitas terhadap variabel Kompetensi $\left(\mathrm{X}_{1}\right)$, Independensi $\left(\mathrm{X}_{2}\right)$ dan variabel Kualitas Audit $\left(\mathrm{X}_{3}\right)$ baik pada kuisioner untuk kelompok sampel auditor internal maupun auditee seluruhnya dinyatakan handal atau reliabel karena nilai koefisien Cronbach's Alpha lebih besar dari 0,60. Hasil uji normalitas pada variabel Kompetensi $\left(\mathrm{X}_{1}\right)$, Independensi $\left(\mathrm{X}_{2}\right)$, dan Kualitas Audit $\left(\mathrm{X}_{3}\right)$ baik pada kuisioner auditor internal maupun auditee memiliki $P$-Value $>\alpha(0,05)$ sehingga dapat disimpulkan bahwa semua variabel berdistribusi normal.

Deskripsi variabel penelitian dirangkum pada tabel berikut:

Tabel 2. Deskriptif Variabel Penelitian

\begin{tabular}{lllrrrr}
\hline No & Variabel & Kelompok Sampel & $\begin{array}{c}\text { Rata- } \\
\text { rata }\end{array}$ & $\begin{array}{c}\text { Standar } \\
\text { Deviasi }\end{array}$ & $\begin{array}{c}\text { Rata- } \\
\text { rata Skor } \\
\text { per Item } \\
\text { Pertanyaan }\end{array}$ & $\begin{array}{c}\text { Gap } \\
\text { Respon } \\
(\%)\end{array}$ \\
\hline 1 & Kompetensi (X1) & Auditor Internal & 59,48 & 8,46 & 5,95 & 2,64 \\
& & Auditee & 57,63 & 8,46 & 5,76 & \\
2 & Independensi (X2) & Auditor Internal & 60,62 & 10,07 & 5,05 & 5,82 \\
& & Auditee & 55,73 & 8,95 & 4,64 & \\
\multirow{2}{*}{3} & Kualitas Audit (X3) & Auditor Internal & 100,67 & 14,28 & 5,92 & 5,76 \\
& & Auditee & 93,82 & 11,61 & 5,52 & \\
\hline
\end{tabular}

Sumber: Hasil Pengolahan Data Penelitian 
Hasil pengujian menggunakan uji-t (Independent t-test) dengan bantuan software SPSS 13 didapatkan hasil sebagai berikut:

Tabel 3. Rangkuman Hasil Pengujian

\begin{tabular}{llllllr}
\hline \multirow{2}{*}{$\begin{array}{c}\text { Variabel } \\
\text { Group }\end{array}$} & \multicolumn{2}{c}{ Lavene's Test } & \multicolumn{2}{c}{ T-Test } \\
\cline { 3 - 7 } & & $\boldsymbol{F}$ & Sig. & $\boldsymbol{t}$ & $\begin{array}{c}\text { Sig. } \\
\text { (2-tailed) }\end{array}$ \\
\hline Kompetensi (X1) & Equal variance assumed & 0.002 & 0.964 & 1.273 & 0.205 \\
& Equal variance not assumed & & & 1.273 & 0.206 \\
Independensi (X2) & Equal variance assumed & 0.027 & 0.869 & 3.021 & 0.003 \\
& Equal variance not assumed & & & 2.961 & 0.004 \\
Kualitas Audit (X3) & Equal variance assumed & 0.166 & 0.685 & 3.120 & 0.002 \\
& Equal variance not assumed & & & 3.012 & 0.003 \\
\hline
\end{tabular}

Sumber: Hasil Pengolahan Data Penelitian

Expectation Gap antara Persepsi Auditor Internal dan Auditee Terkait dengan Kompetensi Auditor Internal

Hasil pengujian Independent t-test pada variabel Kompetensi $\left(\mathrm{X}_{1}\right)$ menunjukkan $P$-Value (disajikan dalam nilai Sig.) sebesar 0,205 yang lebih besar dari $\alpha=0,05$ yang berarti gagal tolak $\mathrm{H}_{0}$ atau dapat diartikan tidak terdapat expectation gap antara persepsi auditor internal dan auditee terkait dengan kompetensi auditor internal atau dengan kata lain bahwa auditee memiliki persepsi yang sama dengan auditor internal dalam hal kompetensi karena indikator kompetensi yang terdiri atas pengetahuan dan pengalaman dipersepsikan sama oleh auditee dan auditor internal. Hal tersebut selaras dengan hasil analisis deskriptif terhadap variabel Kompetensi dimana berdasarkan skor per item pertanyaan antara penilaian auditor internal dan auditee, gap respon terhadap Kompetensi paling kecil dibandingkan dengan gap respon terhadap variabel Independensi dan Kualitas Audit yaitu sebesar 2,64\%. Hal tersebut menunjukkan persepsi auditor internal dan auditee terkait dengan kompetensi tidak terlalu berbeda jauh atau mendekati sama.

Hal ini memungkinkan bahwa auditee lingkup Kementerian Pertanian memiliki persepsi bahwa auditor internal memiliki kompetensi yang memadai dalam melaksanakan audit sesuai dengan persepsi auditor internal dalam menilai kompetensi dirinya sendiri atau kompetensi auditor internal secara umum. Hal tersebut dapat terjadi karena auditor internal dan auditee mempersepsikan kompetensi dari aspek yang sama antara lain auditor internal memiliki latar belakang pendidikan formal yang memadai karena proses rekruitmen di Kementerian Pertanian khususnya Inspektorat Jenderal mensyaratkan pendidikan minimal S1 untuk Jabatan Fungsional Auditor. Selain itu, auditor internal dinilai cukup memiliki pemahaman terkait pemerintahan, pengetahuan tentang bidang tugas dan fungsi auditee, dan pemahaman kondisi instansi yang diaudit karena fungsi auditor internal pada Inspektorat Jenderal Kementerian sebagai consulting partner. Atas dasar fungsi tersebut, Inspektorat Jenderal tidak hanya melaksanakan fungsi audit namun mengaplikasikan dalam beberapa kegiatan lain antara lain Pengawalan/Evaluasi/Pembinaan dan Peningkatan Maturitas SPIP kegiatan strategis satuan/unit kerja lingkup Kementerian Pertanian, serta kegiatan pengawasan lainnya, sehingga auditor internal cukup memahami proses bisnis dari program/kegiatan yang dilaksanakan oleh auditee. 
Tidak adanya expectation gap terkait Kompetensi auditor internal ini sejalan dengan penelitian yang dilakukan oleh Dwi Febri Yandi (2013) yang membuktikan secara empiris bahwa tidak terdapat audit expectation gap dari sisi akuntabilitas, pelaporan audit, independensi auditor, kompetensi auditor, materialitas, bukti audit, pendapat wajar, dan audit kinerja. Namun hasil penelitian ini bertolak belakang dengan hasil penelitian Yudaruddin dan Taufikur Rahman (2014) pada Inspektorat Kota Balikpapan yang membuktikan secara empiris bahwa terdapat expectation gap antara auditor internal dan auditee terkait kompetensi profesional, serta penelitian Rusliyawati dan Abdul Halim (2008) yang membuktikan secara empiris bahwa terdapat audit expectation gap antara auditor pemerintah (BPK) dan pengguna laporan keuangan pemerintah dilihat dari sisi kompetensi auditor. Perbedaan hasil tersebut sangat mungkin terjadi mengingat adanya perbedaan karakteristik responden, waktu pelaksanaan penelitian, ruang lingkup dan batasan penelitian serta faktor-faktor lain.

\section{Expectation Gap antara Persepsi Auditor Internal dan Auditee Terkait dengan Independensi Auditor Internal}

Hasil pengujian Independent t-test pada variabel Independensi $\left(\mathrm{X}_{2}\right)$ menunjukkan $P$-Value (disajikan dalam nilai Sig.) sebesar 0,003 yang kurang dari $\alpha=0,05$ yang berarti tolak $\mathrm{H}_{0}$ atau dapat diartikan terdapat expectation gap antara persepsi auditor internal dan auditee terkait dengan independensi auditor internal. Adanya expectation gap ini selaras dengan hasil analisis deskriptif yang menunjukkan bahwa auditee mempersepsikan Independensi auditor internal lebih rendah yaitu nilai rata-rata persepsi auditee sebesar 55,73 dibandingkan persepsi auditor internal yaitu sebesar 60,62. Selain itu, berdasarkan skor per item pertanyaan antara penilaian auditor internal dan auditee, ratarata auditor internal memberikan nilai sebesar 5,05 dan auditee sebesar 4,67 sehingga antara penilaian auditor internal dan auditee terdapat gap sebesar 5,82\%.

Hal tersebut dapat dijelaskan bahwa, sesuai dengan teori persepsi menurut Robbins (1996) yang menyatakan bahwa persepsi satu individu terhadap satu obyek sangat mungkin memiliki perbedaan dengan persepsi individu yang lain terhadap obyek yang sama, sehingga sangat memungkinkan bahwa persepsi auditor internal dan auditee terhadap Independensi auditor berbeda. Di lingkup Kementerian Pertanian hal tersebut sangat memungkinkan bahwa dari sisi auditor internal dengan berbagai kebijakan dan prosedur di Inspektorat Jenderal antara lain penempatan posisi APIP secara tepat yang bebas dari intervensi, penugasan audit intern yang mengacu kepada Standar Audit dan kepatuhan terhadap Kode Etik serta kebijakan dan prosedur lainnya cukup menjamin independensi auditor internal. Namun, auditee dapat saja masih memiliki persepsi bahwa selama ini auditor internal belum sepenuhnya jujur dan bersih serta mengutamakan kepentingan negara di atas kepentingan pribadi atau golongan, serta persepsi bahwa auditor internal belum seluruhnya bertindak adil tanpa dipengaruhi tekanan dan persepsi bahwa auditor internal belum seluruhnya independen dalam audit yang dilatarbelakangi pengalaman audit sebelumnya, kondisi psikologis auditee, permasalahan di lingkungan satuan/unit kerja, dan faktor lain dapat menjadi sebab adanya perbedaan persepsi dengan auditor internal dalam menilai independensi dirinya sendiri atau independensi auditor internal secara umum sehingga memunculkan expectation gap.

Expectation gap terkait independensi auditor ini sejalan dengan penelitian yang dilakukan oleh Yudaruddin dan Taufikur Rahman (2014) yang telah membuktikan secara empiris bahwa terdapat expectation gap antara auditor internal dan auditee terkait dengan independensi, kompetensi profesional, dan pengawasan Yudaruddin dan Taufikur Rahman (2014). Yeni, N.S. (2000) juga membuktikan 
secara empiris bahwa adanya perbedaan persepsi yang cukup signifikan antara pemakai laporan keuangan, auditor, dan mahasiswa akuntansi mengenai peran dan tanggung jawab auditor dalam isu tanggung jawab auditor terhadap fraud, independensi, tanggung jawab illegal act klien, dan perbaikan keefektivan audit. Selain itu, penelitian oleh Rusliyawati dan Abdul Halim (2008) juga mendukung hasil penelitian dengan hasil pengujian empirisnya yang membuktikan bahwa terdapat audit expectation gap antara auditor pemerintah (BPK) dan pengguna laporan keuangan pemerintah dilihat dari sisi pelaporan, akuntabilitas, independensi auditor, kompetensi auditor, materialitas, bukti audit, pendapat wajar dan audit kinerja.

\section{Expectation Gap antara Persepsi Auditor Internal dan Auditee Terkait dengan Kualitas Audit dari Auditor Internal}

Hasil pengujian Independent t-test pada variabel Kualitas Audit $\left(\mathrm{X}_{3}\right)$ menunjukkan P-Value (disajikan dalam nilai Sig.) sebesar 0,002 yang kurang dari $\alpha=0,05$ yang berarti tolak $\mathrm{H}_{0}$ atau dapat diartikan terdapat expectation gap antara persepsi auditor internal dan auditee terkait dengan Kualitas Audit dari auditor internal. Adanya expectation gap ini selaras dengan hasil analisis deskriptif yang menunjukkan bahwa auditee mempersepsikan Kualitas Audit dari auditor internal lebih rendah yaitu nilai rata-rata persepsi auditee sebesar 93,82 dibandingkan persepsi auditor internal yaitu sebesar 100,67. Selain itu, berdasarkan skor per item pertanyaan antara penilaian auditor internal dan auditee, rata-rata auditor internal memberikan nilai sebesar 5,92 dan auditee sebesar 5,52 sehingga antara penilaian auditor internal dan auditee terdapat gap sebesar 5,76\%.

Hal tersebut dapat dijelaskan bahwa, sesuai dengan teori persepsi sangat memungkinkan bahwa persepsi auditor internal dan auditee terhadap Kualitas Audit dari auditor internal. Inspektorat Jenderal Kementerian Pertanian dalam menjaga kualitas kinerja auditor internal telah menerapkan berbagai upaya dan kebijakan antara lain: 1) Proses perencanaan penugasan melalui tahapan komunikasi dengan auditan melalui surat tugas, persetujuan manajemen atas kriteria audit, dan mengembangkan secara rinci penugasan pengawasan; 2) Pelaksanaan penugasan audit melalui prosedur penerapan audit spesifik, pendokumentasian pelaksanaan prosedur kerja dan hasilnya, serta evaluasi informasi; 3) Pelaporan dan komunikasi hasil audit mencakup prosedur penyiapan laporan hasil penugasan dan penyelenggaraan sistem pemantauan tindak lanjut audit; serta upaya dan kebijakan lainnya. Hal tersebut dinilai auditor internal cukup efektif untuk menjaga Kualitas Hasil Audit. Di sisi lain, auditee dapat saja masih memiliki persepsi bahwa masih terdapat auditor internal yang tidak mempelajari berkas auditee yang akan diaudit, masih adanya auditor internal yang tidak melakukan konfirmasi kepada auditee, penilaian bahwa temuan audit tidak akurat dan ada rekayasa yang dilakukan auditor internal, rekomendasi yang diberikan belum dapat menghilangkan penyebab/ penyimpangan yang ada, serta pelaksanaan audit dan pengiriman laporan tidak tepat waktu dapat menjadi sebab adanya perbedaan persepsi atas Kualitas Hasil Audit. Hal tersebut memunculkan expectation gap dengan persepsi auditor internal dalam menilai kualitas audit dari dirinya sendiri atau kualitas audit dari auditor internal secara umum.

Expectation gap terkait Kualitas Audit ini sejalan dengan penelitian yang dilakukan oleh Simatauw, N.F. dan Taufikur Rahman, SE., M.B.A.Ak. (2014) yang membuktikan secara empiris bahwa terdapat expectation gap antara persepsi Auditor Internal dan auditee terhadap kinerja Auditor Internal terkait dengan pelaksanaan audit dan tindak lanjut audit, serta penelitian oleh M.F.Arrozi Adhikara (2012) yang membuktikan secara empiris bahwa terdapat expectation gap antara auditor, investor, dan akuntan manajemen pada faktor responsibility, reliability, dan decision usefulness dari laporan hasil audit M.F.Arrozi Adhikara (2012). 


\section{Simpulan, Keterbatasan, dan Implikasi Hasil Penelitian}

Berdasarkan hasil analisis dan pembahasan, maka dapat disimpulkan bahwa tidak terdapat expectation gap antara persepsi auditor internal dan auditee terkait dengan kompetensi auditor internal, hal tersebut dapat terjadi karena auditor internal dan auditee mempersepsikan kompetensi dari aspek yang sama antara lain auditor internal memiliki latar belakang pendidikan formal yang memadai karena proses rekruitmen mensyaratkan pendidikan minimal S1 untuk Jabatan Fungsional Auditor dan auditor internal cukup memahami proses bisnis dari program/ kegiatan yang dilaksanakan oleh auditee karena fungsi auditor internal Inspektorat Jenderal Kementerian Pertanian sebagai consulting partner. Namun, hasil analisis terhadap independensi dan kualitas audit menunjukkan terdapat expectation gap antara persepsi auditor internal dan auditee. Adanya expectation gap ini didukung hasil analisis deskriptif yang menunjukkan bahwa auditee mempersepsikan independensi dan kualitas audit lebih rendah dibandingkan persepsi dari auditor internal sendiri. Hal tersebut sangat memungkinkan bahwa dari sisi auditor internal dengan berbagai kebijakan dan prosedur di Inspektorat Jenderal cukup menjamin independensi dan kualitas audit, di sisi lain, auditee dapat saja masih memiliki persepsi yang berbeda dilatarbelakangi pengalaman audit sebelumnya, kondisi psikologis auditee, permasalahan di lingkungan satuan/unit kerja, dan faktor lain.

Evaluasi atas hasil penelitian ini mempertimbangkan keterbatasan yang mungkin mempengaruhi hasil penelitian antara lain penelitian ini kurang mengeksplorasi variabel lain yang mungkin terjadi expectation gap, antara lain akuntabilitas, risiko audit, kepuasan kerja, etika, budaya organisasi, dan variabel lainnya. Hal ini disebabkan karena keterbatasan waktu dan kemampuan peneliti serta pengambilan sampel auditee terbatas pada satuan/unit kerja yang diaudit oleh Inspektorat Jenderal pada Tahun 2017 sehingga variasi responden lebih terbatas.

Implikasi praktis dari penelitian ini bagi Inspektorat Jenderal dapat membuktikan bahwa persepsi auditee terhadap kompetensi, independensi, dan kualitas audit yang lebih rendah dibandingkan persepsi auditor internal dapat digunakan sebagai langkah perbaikan kinerja dan peningkatan kualitas kompetensi, independensi, dan kualitas audit. Implikasi akademis dari penelitian ini dapat digunakan dalam menambah referensi para akademisi yang ingin mengembangkan penelitian tentang audit expectation gap dan dapat bermanfaat bagi pengembangan teori untuk bidang ilmu akuntansi pemerintahan.

\section{Daftar Referensi}

Adhikara, M. F. Arrozi. (2012). Ekspektasi Auditor, Investor, dan Akuntan Manajemen terhadap Pemeriksaan. Jurnal JAM Vol. 23. No. 1: 1-12.

Arikunto, Suharsisni. (2013). Prosedur Penelitian Suatu Pendekatan Praktik. Jakarta: Rineka Cipta.

Ebimobowei, Appah. (2010). An Evaluation of Audit Expectation Gap: Issues and Challenges. Journal Department of Business Education.

Halim, A. dan Rusliyawati. (2008). Penginvestigasian Audit Expectation Gap Pada Sektor Publik.

Hutabarat, J.A.S dan Afri, Y. E. N . (2013). Kesenjangan Harapan Audit Berdasarkan Persepsi Auditor Inspektorat dan Pemakai Laporannya (Studi pada Pemerintah Kota Denpasar, Pemerintah Kabupaten Gianyar). Diponegoro Journal of Accounting, Volume 1, Nomor 1, Tahun 2013.

Porter, Brenda. (1993). An Empirical Study of the Audit Expectation-Performance Gap. Accounting and Business Research Vol 24. pp 49-68. 
Robbins, Stephen P dan Timothy, A. Judge. (1996). Perilaku Organisasi. Jakarta: Penerbit Salemba Empat.

Siddiqui, J. \& Nasreen, T. \& Choudhury, A. (2008). The audit expectations gap and the role of audit education, the case of an emerging economy, University of Manchester, UK, pp: 57-65.

Simatauw, N.F. (2014). Expectation Gap Antara Persepsi Auditor Internal dan Auditee Terhadap Kinerja Auditor Internal Terkait dengan Pelaksanaan, Hasil, dan Tindak Lanjut Audit (Studi Pada Pemerintah Provinsi Maluku). Tesis Program Magister Akuntansi tidak dipublikasikan, Universitas Gajah Mada, Yogyakarta.
Sugiyono. (2011). Metode Penelitian Bisnis. CV Bandung: Alfabeta.

Yeni, N. S. (2000). Persepsi Mahasiswa, Auditor, dan Pemakai Laporan Keuangan Terhadap Peran dan Tanggung Jawab Auditor. Thesis program pasca sarjana tidak dipublikasikan, Universitas Gajah Mada, Yogyakarta.

Yudaruddin dan Rahman. (2014). Persepsi Auditor Internal dan Auditee Terhadap Expectation Gap Terkait Dengan Independensi, Kompetensi Profesional Dan Pengawasan Pada Inspektorat Kota Balikpapan. Jurnal online Universitas Gajah Mada, Volume 7, Februari 2014. 